\title{
VAT Reform in Bangladesh : Perspectives on Tax Morale
}

\author{
Md. Shahiduzzaman Sarkar, Mahpara Nodee, Mahir Musleh, S M Saleh Reza
}

\begin{abstract}
Value-Added Tax (VAT) remains as a strong source of revenue generation in the economy of Bangladesh while tax evasion is rampant in the economy. Taxation is often unpopular and it even might hurt the economy if the tax revenues are not spent well by governments. Policies undertaken by the governments all over the world do not depend solely on benefit of the whole country but also depends on other factors. Personal benefit of politicians, election time, corruption etc. plays a significant role in designing and undertaking policies. VAT is an indirect tax and almost $38 \%$ of National Board of Revenue (NBR) revenue comes from it as per FY2011-2012. For the same fiscal year the income tax contributed almost $30 \%$ of revenues collected by NBR. The paper explores the literature and available data on tax morale - defined as the motivation of a country's citizens to paying taxes. This paper takes a critical look at the Tax morale of the people of Bangladesh. The paper also puts tree diagram to suggest what happens when the government loses public credibility.
\end{abstract}

Keywords_-VAT reform, tax morale, public finance.

\section{Introduction}

Fiscal policies are used by governments to influence the economic activities. These policies include taxation and government spending which affect macroeconomic variables. Often, taxation is disliked and it even might upset the economy if the tax revenues are not utilized efficiently by governments. Policies adopted by the governments all over the world do not hinge solely on benefit of the whole country but also depends on other factors. Personal benefit of politicians, election time, corruption etc. plays a decisive role in designing and undertaking policies. Tax policies are no different.

\section{Md. Shahiduzzaman Sarkar}

Assistant Commissioner

Customs, Excise and VAT, The People's Republic of Bangladesh

Dhaka, Bangladesh

\section{Mahpara Nodee}

Lecturer, United International University

Dhaka, Bangladesh

\section{Mahir Musleh}

McGill University

Montreal, Canada

S M Saleh Reza

Faculty, Daffodil International University

Dhaka, Bangladesh
The foremost revenue collecting agency of Bangladesh is NBR (National Board of Revenue) as it collects $80 \%$ of the total revenue of Bangladesh. Both direct and indirect taxation are under the belt of NBR but indirect tax is the most popular as $70 \%$ of tax revenues comes from indirect taxation and the rest comes from direct taxation. This paper takes a critical look at the Tax morale of the people of Bangladesh. The paper also puts tree diagram to suggest what happens when the government loses public credibility.

\section{What is VAT}

Value-Added Tax (VAT) is an indirect tax and almost 38\% of NBR revenue comes from it as per FY2011-2012. For the same fiscal year the income tax contributed almost $30 \%$ of revenues collected by NBR.

Value-Added Tax (VAT) is a tax on consumer spending. It is collected by VAT-registered traders on their supplies of goods and services effected within the State, for consideration, to their customers. Generally, each such trader in the chain of supply from manufacturer through to retailer charges VAT on his or her sales and is entitled to deduct from this amount the VAT paid on his or her purchases [2].

The effect of offsetting VAT on purchases against VAT on sales is to impose the tax on the added value at each stage of production - hence Value-Added Tax. For the final consumer, not being VAT-registered, VAT simply forms part of the purchase price [2]. With tax evasion being persistent in the economy, only 16 percent of firms file monthly VAT returns, and there is likely substantial evasion among filers [3].

\section{Non Compliance Issues in Tax Collection}

NBR suggests the Non-compliance issues as the following:

- Non-registration

- Non-filing

- Tax delinquency

- Disclosure of lower than actual income 


\section{A. Sources of Noncompliance according to NBR:}

- Awareness Gap: Taxpayers are not aware of the tax obligations and the consequence of noncompliance.

- Support and Service Gap: Taxpayers do not have the proper environment for compliance

- Motivation Gap: Taxpayers do not receive a psychological premium to disclose a higher income

- Enforcement Gap: Taxpayers are habitual defaulters and are inclined to disobey tax laws

Key challenges, non-compliance issues and sources of noncompliance seem to indicate that taxpayers are unwilling to pay taxes. This behavior is not unjustified. Taxes are paid to government to invest in crucial and wanting parts of the economy but is the government of Bangladesh living up to the expectations of the taxpayers?

\section{Iv. Tax Morale}

Bangladesh, as a developing country, still has a long way to go towards the path of economic development. Such development is not possible if the government is not paying enough attention to generate revenues through a strong, transparent and efficient taxation system. Bangladesh was recently declared as one of the lower middle income countries by World Bank, indicating that the number of people with taxable income is growing up, a situation which was supposed to have a positive effect on the ever increasing budget gap or more precisely, the tax gap of the country. The reasons for such imbalance between the budgeted tax income including the VAT and actual tax collection go all the way back to one core reason, lower tax morale of the people of Bangladesh.

The existing literature defines tax morale in different ways. When people believe they should contribute to the society through tax, it may be called tax morale [4]. Also, tax morale is defined as an innate motivation people of a country may have towards paying taxes [5]. In another study, tax morale was stated to be closely related to taxpayer ethics [6]. That is why tax morale is said to be linked to higher tax compliance level [7].

\section{v. Tax Morale in Bangladesh}

People from the developing economies like Bangladesh normally have an adverse attitude towards paying VAT. Saeed argues that a set of varying circumstances including high corruption, low transparency and weak legal framework may lead to having such low tax morale $[8,9]$. Different studies around the world were performed to find out the determinants of tax morale and the extent to which they correlate with tax morale. Socio-economic factors such as age, gender, religion, employment status, educational attainment as well as institutional determinants, for example, trust in the government and democracy, perception regarding the public goods and services both impact the level of tax morale [10].
There always remains a relationship between paying taxes to the government and getting to know the eventual, successful utilization of those funds [10]. In Bangladesh, people eligible to pay taxes and VAT often feel deceived by the government. The apprehension people have about not receiving the value for money they are paying in the forms of tax and VAT results in lowering the tax morale among them. Payment of the required tax, VAT and investment of those in development projects of the government is a twoway process. Unless there is promised transparency, efficiency and accountability from government's end, it is unlikely that people will opt for paying such levies imposed upon them. The government does not always disclose the projects where the funds are invested and whether any positive return is yielded for the public. This causes the tax morale to drop, even for an honest tax payer. Daude argues that a positive perception regarding the democracy of the country and controlled corruption relates to higher tax morale, following the acceptance of imposed tax to be legitimate [10].

The people of Bangladesh do not seem to have a positive perception about the overall taxation system and the tax administration of the country. Saeed argued that, according to Kiyosaki, (2011), the tax system across countries is unjust and it actually penalizes those who produce more $[9,11]$. Moreover, the economy of Bangladesh also faces the freerider problem, a situation where non-payers of taxes are enjoying the benefits of the public goods and services. This demotivates the existing honest tax payers of the country and harms their tax morale, keeping them off of contributing further into the development of their very country. That's why "Daude, Gutie'rrez, \& Melguizo" presented a strong positive correlation between tax morale and objection towards free riding in the economy[10].

Low tax morale exists in Bangladesh not only in individual level but also in corporate level [12]. Companies face mandatory high tax compliance costs ranging from collecting basic information, filling out tax returns to hidden tax compliance cost, such as payment to the tax lawyers for staying within tax advantage bracket. The World Bank's indicator for time to prepare and pay taxes in hours per year was last published for 2014, showing large differences among countries with Bangladesh having a score of 302 hours, way much for a small developing country waiting to become fully digitalized. So, going through a cost-benefit analysis reveals rather higher administrative burden to comply with imposed tax burden. As a result, MNCs in Bangladesh often go for illegal transfer pricing to evade tax and VAT. For a country with the above mentioned hurdles in various far stretched sectors, it is not unusual to state that individuals and corporations here are not born with low tax morale, rather they are grasped by it over time.

Bangladesh lacks transparency and information about government spending lacks credibility. There is usually a mismatch between input of and output when it comes to government spending. It is widely known that the administration is riddled with corruption. When people's money are not even used near its potential, people not paying taxes and hiding their income is a validated behavior. To improve the 'tax morale' of Bangladesh the government needs to analyze and improve the determinants of tax compliance. 
The attitude of taxpayers towards compliance is determined by business, industry, sociological, economic and psychological aspects (OECD, 2004).When public starts to reap benefits from these determinants and understand that government is helping them to reap the benefits through the payment of taxes that are latter invested on the determinants, the public will be encouraged to pay taxes. This, of course, does not necessarily mean that most of the people will pay taxes as in Bangladesh there exist taxpayers who are habitual defaulters and are predisposed to disobey tax laws

Gaining trust and confidence of the public is very important when it comes to collecting taxes. Now how can the general people trust a government/s when the people know that they are being cheated for years? The people now know that, probably, a massive amount of their money ends up in crooked politicians' pockets. To gain the trust back/ for the first time the government needs to fulfill their commitment not for once but for many time. But there is a catch. If government does not earn more revenues through taxes, how can they spend more? There is a chicken-egg argument here. Should the public trust the government and pay them at first and see what does the government do with their money or should the government somehow manage finance (probably by borrowing) and undertake projects.

Given that the majority of public (general people and businesses) does not trust the government and hence not paying taxes, the following might occur in Figure 1.

Figure 1: Decision Tree of citizens on paying tax when they do not trust the government

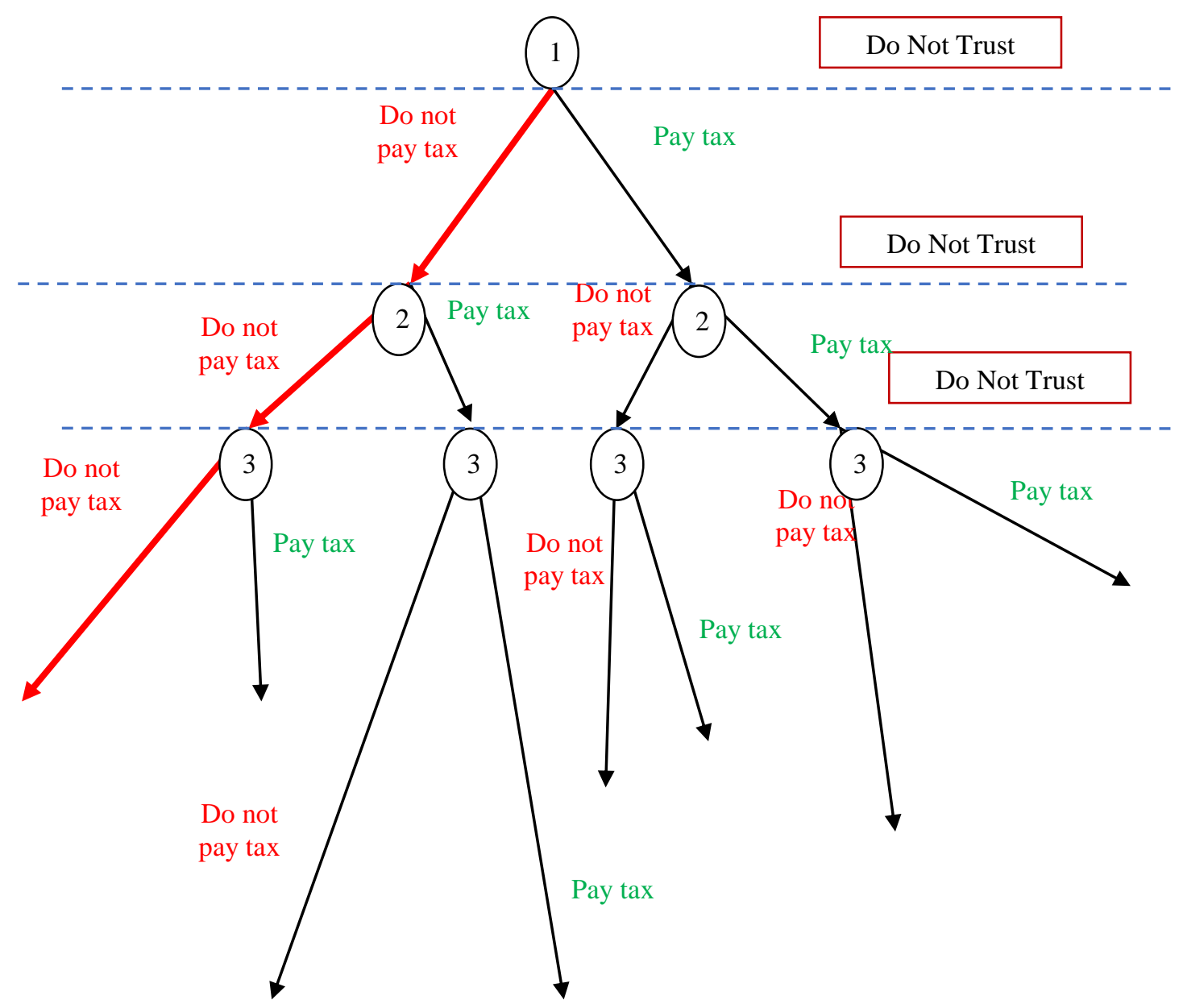


If the public do not trust the government they will be unwilling to pay taxes and the game will follow the dreaded bold red path in the above diagram where the distance between the government and the public is increasing; and also the public trust on the government is tending to be extinct. The government has to regain trust and influence the public to follow the green path in the following diagram.

Figure 2: Decision Tree of citizens on paying tax when they trust the

government

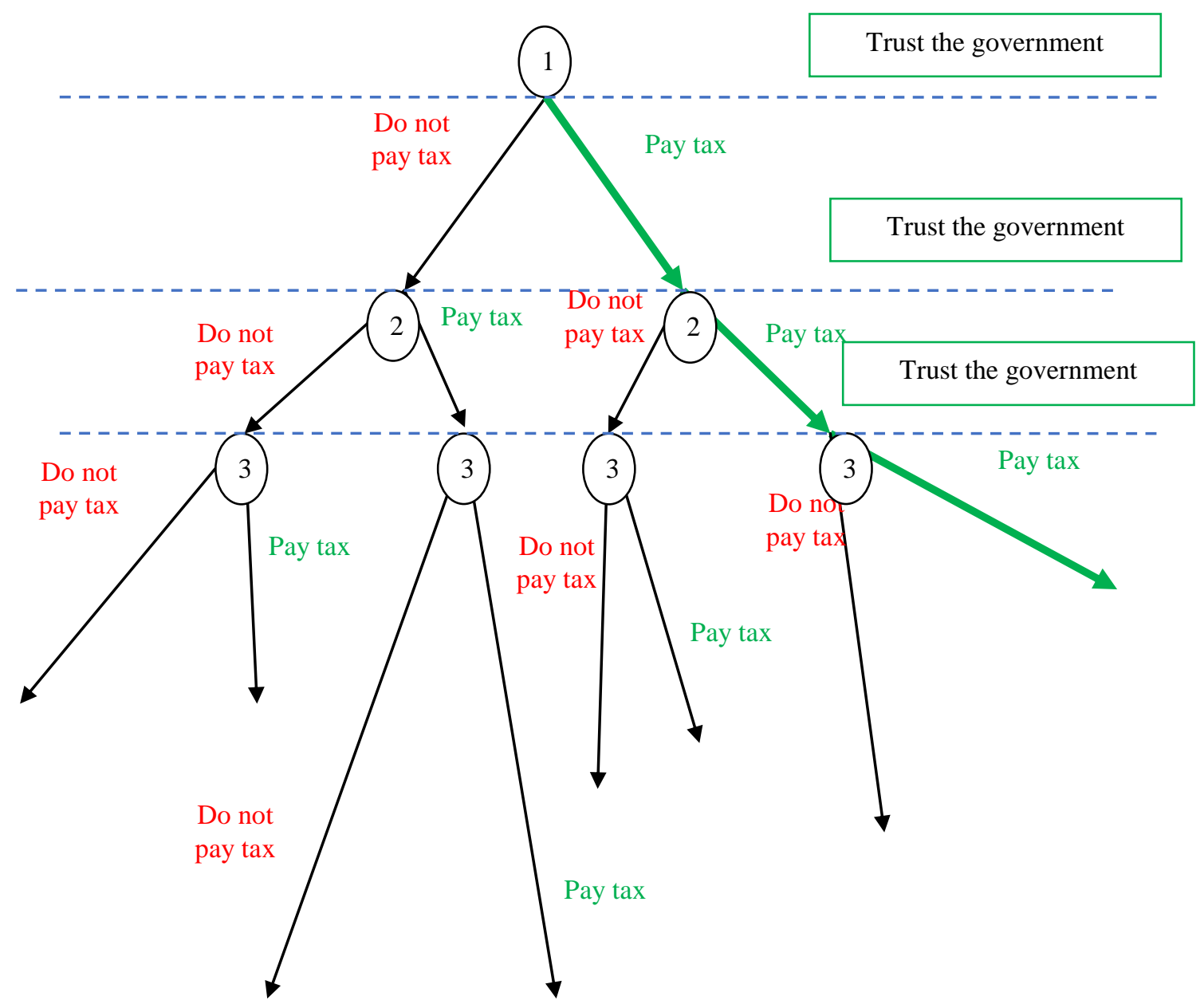

\section{vi. Conclusion}

People pay VAT because they are forced to conform to the government rules and regulations [10]. But it is not far that the number of people characterized by low tax morale in Bangladesh will reach a stage beyond controlling. To combat that situation, government of Bangladesh needs to take some steps in line with countries facing similar circumstances.

Firstly, the willingness of people to pay VAT needs to be increased through motivating them both by the government and by others specialized in the field. Government of Bangladesh needs to ensure taxpayer education on an emergency basis. If people are oriented with the projects and investments on which government is spending their tax money, they have a feeling of close association with the country and are ready pay for its' overall economic development. The government should disclose time to time the budget implementation plan of VAT and the progress reports should also be made available to the public. On the other hand, government should familiarize itself with the loopholes of current VAT act and revise the act accordingly. As a result, people will learn that efforts are made to value their money paid out as VAT. 
Secondly, thinking of tax enforcement as legitimate and of corruption to be under control come out as perks of having high tax morale [10]. Government should formulate agendas about combating corruption in tax administration. When conducting a regional analysis directed to find out the drivers of tax morale, it was found that affirmative perception by people of public officials directly associated with tax issues, helps a lot to boost the tax morale of people. Also, the extent to which people are satisfied with the Additionally, the established VAT code should be enforced strictly throughout the country, maintaining the sanctions and penalties due to non-compliance. Monitoring teams should be established by NBR to oversee whether VAT codes are followed. In Pakistan, government threatens the non-tax payers to auction their properties on the event of non-payment [9]. So, motivation to comply with VAT is backed by fear of penalty. Tekeli noted that, both Japan and Turkey have severe penalty structures for tax evasions, whether done unintentionally or to commit fraud [7]. On the other hand, people should feel respected by the government. While dealing with strict measures and penalties, government should also keep in mind that it is the valued citizens, upon whom the overall economic growth largely depends. According to the report of Feld and Frey, when at the same time, Switzerland authorities treated taxpayers more respectfully and imposed heavy penalties for nondeclaration, more encouraging results came out [13].

As mentioned earlier, putting trust in the government and administrative body along with achieving further economic development through a better and well-functioning force is a two-way process. One cannot be ensured without the other. Education to make people aware and laws to implement public policy play side by side role in this regard. In line With other cross-country studies in this field, socio-

\section{References}

[1] G. Eason, B. Noble, and I. N. Sneddon, "On certain integrals of Lipschitz-Hankel type involving products of Bessel functions," Phil. Trans. Roy. Soc. London, vol. A247, pp. 529-551, April 1955. (references)

[2] http://www.revenue.ie/en/tax/vat/

[3] http://www.povertyactionlab.org/evaluation/impact-social-incentivestax-compliance-and-revenue-bangladesh)

[4] Torgler, B., \& Schneider, F. (2009). The impact of tax morale and institutional quality on the shadow economy. Journal of Economic Psychology, 30(2), 228-245.

[5] Cummings, R. G., Martinez-Vazquez, J., McKee, M., \& Torgler, B. (2009). Tax morale affects tax compliance: Evidence from surveys and an artefactual field experiment. Journal of Economic Behavior \& Organization, 70(3), 447-457.

[6] Alm, J., \& Torgler, B. (2006). Culture differences and tax morale in the United States and in Europe. Journal of Economic Psychology, 27(2), 224-246.

[7] Tekeli, R. (2011). The Determinants of Tax Morale: the Effects of Cultural Differences and Politics. Japan: Policy Research Institute, Ministry of Finance.

[8] Torgler, B., \& Schneider, F. (2007). What shapes attitudes toward paying taxes? Evidence from multicultural European countries. Social Science Quarterly, 88(2), 443-470.

[9] Saeed, A., \& Shah, A. (2011). Enhancing tax morale with marketing tactics: A review of literature. African Journal of Business Management, 13559-13565.

[10] Daude, C., Gutie`rrez, H., \& Melguizo, A. (2012). What Drives Tax Morale? OECD Publishing.

[11] Kiyosaki, R. T. (2011). Rich Dad Poor Dad. Plata Publishing, LLC. quality of public service determines the level of tax morale among them [10]. In Brazil, new set of tax reforms were introduced in 1989 including bonus incentives for the honest and efficient tax collector officials [9]. A benchmark should be set out to follow in accordance with other countries that are successful in this arena. A complete successful VAT reform in Bangladesh would not be possible unless the government puts forth its best effort on the above key areas.

Economic variables should also be analyzed to identify their extent of influence on the level of tax morale of the people of Bangladesh. VAT reform gets only easier in a country like Bangladesh if there are people charged up with high tax morale.

Official development assistance (ODA) is decreasing for Bangladesh. It is crucial that Bangladesh attains a high degree of self-sufficiency in terms of revenue and expenditure. Therefore Bangladesh government should start the project of gaining public trust immediately. Current projects in hand should be completed with brutal efficiency and crystal clear transparency.

When government gains the confidence of the public the government will have the right to tax the public. After the government finishes projects with minimum corruption and maximum efficiency the public has to pay taxes. If they do not pay taxes and undertake evasive maneuvers they are to be caught and punished. The first step should be encouraging the public to pay by gaining their confidence and trust. Then, the ones who do not comply with taxation policies they are to be punished and appropriate enforcement must be carried out. Moreover, penalties should make taxpayers comply with tax laws.
[12] Hasan, R. (2013). The Tendency toward Tax Evasion in Bangladesh.

[13] Feld, L. P., \& Frey, B. S. (2002). Trust Breeds Trust: How Taxpayers are Treated. Economics of Governance, 87-99.

About Author (s):

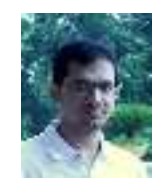

Md. Shahiduzzaman Sarkar is serving The People's Republic of Bangladesh as an Assistant Commissioner of Customs, Excise and VAT.

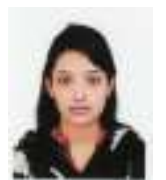

Mahpara Nodee is currently working as a lecturer of accounting in United International University, Dhaka. Her research interests include risk management, ethics in financial reporting, budgeting and public finance etc.

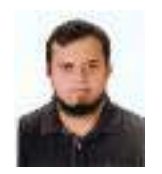

Mahir Musleh is currently pursuing his Masters in Economics in McGill University, Canada. His research interest includes Economic Growth, Unemployment etc.

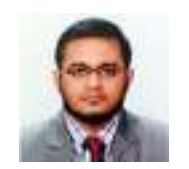

S M Saleh Reza is currently teaching at Daffodil International University. $\mathrm{He}$ is also a $\mathrm{PhD}$ researcher at Bangladesh University of Professionals. 